\title{
Clinical features and management of hereditary spastic paraplegia
}

\author{
Aspectos clínicos e manejo das paraplegias espásticas hereditárias \\ Ingrid Faber', Katiane R. Servelhere', Alberto R. M. Martinez', Anelyssa D’Abreu', Iscia Lopes-Cendes², \\ Marcondes C. França-Jr ${ }^{1}$
}

\begin{abstract}
Hereditary spastic paraplegia (HSP) is a group of genetically-determined disorders characterized by progressive spasticity and weakness of lower limbs. An apparently sporadic case of adult-onset spastic paraplegia is a frequent clinical problem and a significant proportion of cases are likely to be of genetic origin. HSP is clinically divided into pure and complicated forms. The later present with a wide range of additional neurological and systemic features. To date, there are up to 60 genetic subtypes described. All modes of monogenic inheritance have been described: autosomal dominant, autosomal recessive, X-linked and mitochondrial traits. Recent advances point to abnormal axonal transport as a key mechanism leading to the degeneration of the long motor neuron axons in the central nervous system in HSP. In this review we aim to address recent advances in the field, placing emphasis on key diagnostic features that will help practicing neurologists to identify and manage these conditions.
\end{abstract}

Keywords: hereditary spastic paraplegia, spastic paraplegia, muscle spasticity, genetics, mutation.

\section{RESUMO}

Paraplegias espásticas hereditárias (PEH) constituem um grupo de desordens geneticamente determinadas caracterizadas por espasticidade e paraparesia de progressão insidiosa. Paraplegia espástica aparentemente esporádica de início no adulto constitui problema frequente na prática neurológica. Evidências recentes sugerem que uma proporção significativa destes casos é geneticamente determinada. O grupo das PEH é dividido clinicamente em formas puras e complicadas de acordo com a concomitância de outras manifestações clinicas e neurológicas. Até o momento 60 tipos genéticos foram identificados. Todos os modos de herança monogênica já foram descritos: autossômica dominante, autossômica recessiva, ligada ao X e mitocondrial. Avanços recentes indicam que alterações do transporte axonal estão implicadas na degeneração dos longos axônios motores no sistema nervoso central na PEH. Nesta revisão abordamos recentes avanços na área com ênfase nos aspectos clínicos chave que ajudam o neurologista geral no diagnóstico e manejo correto deste grupo de doenças.

Palavras-chave: paraplegia espástica hereditária, paraplegia espástica, espasticidade muscular, genética, mutação.

Hereditary spastic paraplegia (HSP) is a diverse group of single-gene disorders characterized by retrograde degeneration of the long axonal fibers of the corticospinal tracts and posterior columns of the spinal cord. The key clinical feature is slowly progressive pyramidal pattern of weakness ${ }^{1}$.

There are few epidemiological studies in HSP, but prevalence is estimated to range between 1.3 to 9.6 cases per 100,000 people $^{2}$. In addition to clearly familial cases, a significant proportion of patients with sporadic spastic paraplegia also have a genetic etiology. HSP represents a large proportion of subjects attending specialized Movement
Disorders, Neuromuscular and Neurogenetics outpatient clinics. Although traditionally regarded as a rare disorder, HSP is almost as common as other disorders well known by the general neurologist, such as: hereditary cerebellar ataxias (prevalence rate of up to 8.9 people out of $100,000)^{3}$, motor neuron disease $(6.3 \text { per } 100,000)^{4,5}$ and multiple system atrophy (4-5 per 100,000 people) ${ }^{6}$.

In recent years, several genes and loci associated to HSP have been mapped ${ }^{1,7}$. On clinical grounds, these findings helped neurologists to perform more accurate and earlier diagnoses, as well as a sounder genetic counseling.

${ }^{1}$ Departamento de Neurologia, Faculdade de Ciências Médicas, Universidade Estadual de Campinas, Campinas SP, Brazil. ${ }^{2}$ Departamento de Genética Médica, Faculdade de Ciências Médicas, Universidade Estadual de Campinas, Campinas SP, Brazil.

Correspondence: Marcondes C. França Junior; Departamento de Neurologia, Universidade de Campinas; Rua Tessália Vieira de Camargo, 126. Cidade Universitária "Zeferino Vaz"; 13083-887 Campinas SP - Brasil; E-mail: mcfrancajr@uol.com.br

Support: Fundação de Amparo à Pesquisa do Estado de São Paulo (FAPESP).

Conflict of interest: There is no conflict of interest to declare.

Received 30 August 2013; Received in final form 09 November 2013; Accepted 29 November 2013. 
Furthermore, key molecular pathways leading to neurodegeneration were unraveled, which might have short term implications for novel therapies and result in a better understanding of closely related disorders, such as motor neuron diseases and spinocerebellar ataxias.

In the present article, we review the core clinical features of HSP, as well as the available therapeutic strategies. Our ultimate objective is to help practicing neurologists to recognize and to properly manage patients with HSP.

\section{CLASSIFICATION}

HSPs are a group of heterogeneous monogenic diseases. They may segregate as an autosomal dominant, an autosomal recessive, $\mathrm{X}$-linked or mitochondrial trait ${ }^{1}$. To date, there are up to 60 genetic types described ${ }^{7}$. Clinically, they are classified as pure or complicated forms. The later are associated with a variety of other neurological and systemic abnormalities, whereas the former essentially present with lower limb weakness and spasticity. Most cases of pure HSP are autosomal dominant, while complicated forms are inherited mostly as autosomal recessive conditions. X-linked forms may present either as pure or complicated HSP. This distinction is clinically useful, but is not always found in genotypephenotype correlation studies ${ }^{1}$.

\section{AUTOSOMAL DOMINANT- HEREDITARY SPASTIC PARAPLEGIA (AD-HSP)}

AD-HSP represents $70 \%$ to $80 \%$ of HSPs. Almost half of those are caused by mutations in the SPG4 gene that encodes for the protein spastin ${ }^{8}$. SPG4 is also responsible for approximately $10 \%$ of sporadic cases. In Brazil, we have recently found that SPG4-related HSP accounts for $35 \%$ of $\mathrm{AD}$ cases $^{9}$. It shows a wide inter and intra-familial variability in age of onset and disease severity suggesting the existence of modifying factors ${ }^{10}$. It classically presents as a pure spastic paraplegia. Recent studies though highlighted a frequent association with cognitive decline, hand tremor and other complicating features ${ }^{11,12}$.

Table 1. Current genetic classification of autosomal dominant hereditary spastic paraplegia.

\begin{tabular}{|c|c|c|c|}
\hline Disease & Gene symbol locus & Protein & Key clinical features \\
\hline SPG3A & $\begin{array}{l}\text { SPG3A } \\
14 q 22.1\end{array}$ & Atlastin & Pure early onset. \\
\hline SPG4 & $\begin{array}{l}\text { SPAST } \\
2 \mathrm{p} 24-\mathrm{p} 21\end{array}$ & Spastin & $\begin{array}{c}\text { pure HSP, highly variable onset. Late onset } \\
\text { cognitive impairment. }\end{array}$ \\
\hline SPG6 & $\begin{array}{l}\text { NIPA1 } \\
15 q 11.2\end{array}$ & $\begin{array}{l}\text { NIPA1 (Not imprinted in } \\
\text { Prader-Willi/Angelman 1) }\end{array}$ & Pure, slowly progressive adult-onset. \\
\hline SPG8 & $\begin{array}{l}\text { KIAA0196 } \\
\text { 8q24.13 }\end{array}$ & Strumpellin & Pure adult-onset. \\
\hline SPG9 & $\begin{array}{l}\text { Gene unknown } \\
\text { 10q23.3-q24.1 }\end{array}$ & Unknown & $\begin{array}{c}\text { Complicated: Cataracts, motor neuropathy, } \\
\text { gastroesophageal reflux. }\end{array}$ \\
\hline SPG10 & $\begin{array}{c}\text { KIF5A } \\
12 q 13.13\end{array}$ & Kinesin Family member $5 \mathrm{~A}$ & Pure or Complicated. Early-onset, distal amyotrophy. \\
\hline SPG12 & $\begin{array}{l}\text { RTN2 } \\
19 q 13\end{array}$ & Reticulon 2 & Pure, early-onset. \\
\hline SPG13 & $\begin{array}{l}\text { HSPD1 } \\
2 q 33.1\end{array}$ & $\begin{array}{l}\text { Heat shok 60KDa protein } 1 \\
\text { (chaperonin) (M) }\end{array}$ & Pure, adult-onset. \\
\hline SPG17 & $\begin{array}{c}B S C L 2 \\
11 q 12-q 13.5\end{array}$ & Seipin & $\begin{array}{c}\text { Complicated: amyothrophy of hand muscles } \\
\text { (Silver-syndrome). }\end{array}$ \\
\hline SPG19 & $\begin{array}{l}\text { Gene unknown } \\
\text { 9q33-q34 }\end{array}$ & Unknown & Pure. \\
\hline SPG29 & $1 p 31-p 21$ & Unknown & $\begin{array}{c}\text { Complicated: deafness, persistent vomiting } \\
\text { from hiatal hernia. }\end{array}$ \\
\hline SPG31 & $\begin{array}{l}\text { REEP1 } \\
2 \mathrm{p} 11.2\end{array}$ & $\begin{array}{l}\text { Receptor expression } \\
\text { enhancing protein } 1 \text { (REEP1) }\end{array}$ & Pure. May be complicated by Silver-syndrome. \\
\hline SPG33 & $\begin{array}{l}\text { ZFYVE27 } \\
10 q 24.2\end{array}$ & Protrudin & Pure. \\
\hline SPG36 & $\begin{array}{l}\text { Gene unknown } \\
12 q 23-q 24\end{array}$ & Unknown & Early adulthood associated with polyneuropathy. \\
\hline SPG37 & $\begin{array}{l}\text { Gene unknown } \\
8 p 21.1-q 13.3\end{array}$ & Unknown & Pure. \\
\hline SPG38 & $\begin{array}{l}\text { Gene unknown } \\
\text { 4p16-p15 }\end{array}$ & Unknown & Complicated: Silver-syndrome. \\
\hline SPG41 & $\begin{array}{l}\text { Gene Unknown } \\
11 \mathrm{p} 14.1-\mathrm{p} 11.2\end{array}$ & Unknown & Pure or mild Silver-syndrome. \\
\hline SPG42 & $\begin{array}{l}\text { SCL33A1 } \\
\text { 3q25.3 }\end{array}$ & $\begin{array}{l}\text { SCL33A1 (acetyl-CoA } \\
\text { transporter) }\end{array}$ & Pure, variable-onset incomplete penetrance. \\
\hline
\end{tabular}


Mutations in the SPG3a gene, encoding for the protein atlastin- 1 , are the second most common cause of AD-HSP and the most common cause of early-onset disease ${ }^{13}$. Most patients present with pure spastic paraplegia initiating before the age of ten. $S P G$ 31, related to mutations in the REEP 1 gene, accounts for approximately 5\% of AD-HSP. It typically presents as early-onset spastic paraplegia plus lower motor neuron disease, known as Silver-syndrome ${ }^{14}$.

Mutations in the SPG $6^{15}$ and SPG $8^{16}$ are pure HSPs that have already been identified in the Brazilian population. SPG 6 presents as a slowly progressive, mostly pure spastic paraplegia in early-adulthood ${ }^{15}$ (Table 1).

\section{AUTOSOMAL RECESSIVE- HEREDITARY SPASTIC PARAPLEGIA (AR-HSP)}

AR-HSP frequently present with pleomorphic associated neurological and clinical abnormalities. While this adds considerable challenges in the diagnostic workup, certain specific complicating features may guide the differential diagnosis between the different HSPs. As seen in other recessive conditions, AR-HSP are more frequent in consanguineous populations.

Mutations in the gene SPG11, encoding spastacsin, are the most frequent cause of AR-HSP, corresponding to up to $20 \%{ }^{17}$. This proportion increases to $60-80 \%$ when considering patients with thinning of the corpus callosum and mental impairment ${ }^{18}$. Patients typically present around the first or second decades with gait disturbances followed by cognitive deterioration, peripheral neuropathy and movement disorders, including dopa-responsive parkinsonism ${ }^{19}$. Thinning of the corpus callosum is a hallmark of this condition. In our center, SPG 11-HSP accounts for $45 \%$ of patients with HSP and thinning of the corpus callosum ${ }^{20}$. Atrophy of the corpus callosum is also a hallmark of $S P G 15$, associated with pigmental retinopathy and polyneuropathy ${ }^{21}$. Mutations in the $S P G 7$ gene, which encodes paraplegin, is the second most common cause of AR-HSP. Its characteristic features include cerebellar ataxia, peripheral neuropathy and optic atrophy ${ }^{22}$. SPOAN syndrome, first described in Brazil is characterized by early and rapidly progressive spastic paraplegia, optic atrophy and peripheral neuropathy, but its gene is yet to be identified ${ }^{23}$ (Table 2).

\section{X-LINKED}

SPG1 gene encodes the protein $\mathrm{NCAM}^{24}$. Affected males typically present with spastic paraplegia and hydrocephalus, together with mental retardation, aphasia, shuffling gait and adducted thumbs (MASA-syndrome).
$S P G 2$ gene is also called proteolipoprotein or PLP1 gene $^{25}$. The typical phenotype is composed of spastic paraplegia associated with peripheral neuropathy and white matter abnormalities. Interestingly, duplications of this gene give rise to the congenital hipomyelinating Pelizaeus-Merzbacher disease $^{25}$. SPG34 disease is a pure X-linked form of HSP whose locus was first identified in Brazil, but its gene is yet to be identified ${ }^{26,27}$ (Table 3).

\section{MITOCHONDRIAL}

A single family with five affected members has been recently described with a mtDNA mutation in the ATP6 gene clinically expressed as late onset spastic paraplegia ${ }^{28}$.

\section{DIAGNOSIS}

Diagnosis of HSP is based upon individual and familyhistory as well as clinical and neurological findings such as spastic weakness, hyperreflexia and extensor plantar responses. These will guide further investigation to rule out acquired causes of spastic paraplegia and orient specific molecular diagnosis. The absence of family history should not eliminate the diagnosis of HSP. At times, mildly affected members or false paternity are not recognized, so a detailed history and examination of apparently healthy family members is desirable. HSP is characterized by normal motor development followed by slowly progressive spasticity and weakness of the lower limbs. The clinical spectrum and the age of onset vary widely. Disproportionate spasticity in contrast with mild weakness is a hallmark of this disorder. Mild reduction of vibration sense, or other sensory abnormalities together with urinary symptoms are frequent even in pure forms ${ }^{1}$. Complicated HSP comprise a large number of abnormalities such as ataxia, peripheral neuropathy, amyotrophy, seizures, movement disorders, cognitive impairment, retinopathy, optic atrophy, deafness and others ${ }^{29,30}$.

An apparently sporadic case of slowly progressive spasticity and weakness of the lower limbs is a fairly frequent clinical problem in neurological practice. HSP is a diagnosis of exclusion, especially in the absence of family history. Spinal cord compression, infectious, inflammatory, metabolic and ischemic myelopathies must be ruled out. We suggest a basic workup composed of: serology for human $\mathrm{T}$ cell leukemia virus, HIV and syphilis, as well as measurement of serum copper, ceruloplasmin, ferritin, vitamin B12 and vitamin $E$ levels. In selected cases, quantification of serum very long chain fatty acids may be desirable to screen for adrenomyeloneuropathy. Magnetic resonance of the cervical spine is necessary to exclude spinal cord compression, inflammatory or ischemic myelopathies. Brain MRI is desirable since it 
Table 2. Current genetic classification of autosomal recessive hereditary spastic paraplegia.

\begin{tabular}{|c|c|c|c|}
\hline Disease & iene symbol locus & Protein & Key clinical features \\
\hline SPG5 & $\begin{array}{l}\text { CYP7B1 } \\
8 p 12-q 13\end{array}$ & $\begin{array}{l}\text { Cytochrome P450, family } 7 \\
\text { subfamily } B \text {, polypeptide } 1\end{array}$ & Pure or complicated: generalized muscle atrophy and white matter lesions. \\
\hline SPG7 & $\begin{array}{l}S P G 7 \\
16 q 24.3\end{array}$ & Paraplegin & $\begin{array}{c}\text { Pure and complicate: amyotrophy, dysarthria, dysphasia, cerebellar } \\
\text { and optic atrophy. }\end{array}$ \\
\hline SPG11 & $\begin{array}{l}\text { SPG11 } \\
15 q 14\end{array}$ & Spatacsin & $\begin{array}{c}\text { Pure and complicated/early onset, cognitive impairment, neuropathy, } \\
\text { movement disorders, TCC. }\end{array}$ \\
\hline SPG14 & $\begin{array}{l}\text { Gene Unknown } \\
3 q 27-q 28\end{array}$ & Unknown & Complicated: polineuropathy, mental retardation. \\
\hline $\begin{array}{l}\text { SPG15 } \\
\text { (Kjellin) }\end{array}$ & $\begin{array}{l}\text { ZFYVE26 } \\
14 q 24.1\end{array}$ & Spastizin & $\begin{array}{l}\text { Complicated: spastic paraplegia with macular dystrophy, mental } \\
\text { retardation and amyotrophia (Kjellin syndrome). }\end{array}$ \\
\hline SPG18 & $\begin{array}{l}\text { ERLIN2 } \\
\text { p11.23 }\end{array}$ & Erlin-2 & Complicated: mental retardation, TCC. \\
\hline $\begin{array}{l}\text { SPG20 } \\
\text { (Troyer) }\end{array}$ & $\begin{array}{l}S P G 20 \\
13 q 12.3\end{array}$ & Spartin & Complicated: dysarthria and distal amyotrophy. \\
\hline $\begin{array}{l}\text { SPG21 } \\
\text { (Mast) }\end{array}$ & $\begin{array}{l}S P G 21 \\
15 q 21-q 22\end{array}$ & Maspardin & $\begin{array}{c}\text { Complicated: cognitive decline, movement disorders, TCC, white } \\
\text { matter abnormalities. }\end{array}$ \\
\hline $\begin{array}{l}\text { SPG23 } \\
\text { (Lison) }\end{array}$ & $\begin{array}{l}\text { Gene unknown } \\
\text { 1q24-q32 }\end{array}$ & Unknown & Complicated/skin and hair pigmentary lesions, skeletal abnormalities. \\
\hline SPG24 & $\begin{array}{l}\text { Gene unknown } \\
13 q^{14}\end{array}$ & Unknown & Pure/spastic dysarthria and pseudobulbar signs \\
\hline SPG25 & $\begin{array}{l}\text { Gene unknown } \\
6 \mathrm{q} 23.3-\mathrm{q} 24.1\end{array}$ & Unknown & Complicated: multiple disc herniation, cataract, congenital glaucoma. \\
\hline SPG26 & $\begin{array}{l}\text { Gene unknown } \\
12 p 11-q 14\end{array}$ & Unknown & $\begin{array}{c}\text { Child onset, complicated:distal amyotrophy cognitive impairment, } \\
\text { dysarthria. }\end{array}$ \\
\hline SPG27 & $\begin{array}{l}\text { Gene unknown } \\
10 q 22-q 24\end{array}$ & Unknown & $\begin{array}{c}\text { Pure or complicated: cognitive impairment, ataxia, dysarthria, } \\
\text { polyneuropathy, short stature, dismorphic face. }\end{array}$ \\
\hline SPG28 & $\begin{array}{l}\text { DDHD1 } \\
14 q 22.1\end{array}$ & DDHD1 & Pure early-onset. \\
\hline SPG29 & $\begin{array}{l}\text { Gene unknown } \\
1 \mathrm{p} 31.1-\mathrm{p} 21.1\end{array}$ & Unknown & Pure, childhood onset. \\
\hline SPG30 & $\begin{array}{l}\text { KIF1A } \\
2 q 37.3\end{array}$ & Kinesin family member $1 \mathrm{~A}$ & Complicated: ataxia, sensory neuropathy. \\
\hline SPG32 & $\begin{array}{l}\text { Gene unknown } \\
14 q 12-q 21\end{array}$ & Unknown & $\begin{array}{c}\text { Complicated: mental retardation, ataxia, brainstem dysraphia and } \\
\text { cerebellar atrophy. }\end{array}$ \\
\hline SPG35 & $\begin{array}{c}F A 2 H \\
16 q 21-q 23.1\end{array}$ & Fatty acid 2-hydroxilase & $\begin{array}{l}\text { Childhood onset, complicated: cognitive decline, movement disorders, } \\
\text { epilepsy. Brain white matter lesions and iron accumulation. }\end{array}$ \\
\hline SPG39 & $\begin{array}{l}\text { PNPLA6 } \\
19 p 13.2\end{array}$ & $\begin{array}{c}\text { Neuropathy Target Esterase } \\
\text { (NTE) }\end{array}$ & Complicated: childhood onset, marked distal wasting in all four limbs. \\
\hline SPG43 & $\begin{array}{l}\text { Gene unknown } \\
19 p 13.11-q 12\end{array}$ & Unknown & Complicated: Silver-syndrome and dysarthria. \\
\hline SPG44 & $\begin{array}{l}\text { CJC2 } \\
1 \mathrm{q} 42.13\end{array}$ & Connexin 47 & $\begin{array}{l}\text { Adulthood onset complicated: cognitive decline, spasticity of } \\
\text { four limbs. }\end{array}$ \\
\hline SPG45 & $\begin{array}{l}\text { Gene unknown } \\
10 q 24.3-q 25.1\end{array}$ & Unknown & Childhood onset complicated: mental retardation, optic athrophy. \\
\hline SPG46 & $\begin{array}{l}\text { Gene unknown } \\
9 p 21.2-q 21.12\end{array}$ & Unknown & Dementia, congenital cataract, ataxia, TCC. \\
\hline SPG47 & $\begin{array}{l}A P 4 B 1 \\
1 \mathrm{p} 13.2\end{array}$ & AP-4 complex subunit beta-1 & $\begin{array}{l}\text { Complicated: neonatal hypotonia, progressive hypertonia, } \\
\text { severe mental retardation, ataxia, seizures, TCC. }\end{array}$ \\
\hline SPG48 & $\begin{array}{l}\text { KIAA0415 } \\
7 \mathrm{p} 22.1\end{array}$ & KIAA0415 & Pure. \\
\hline SPG49 & $\begin{array}{l}\text { TECPR2 } \\
14 \mathrm{q} 32.31\end{array}$ & Unknown & $\begin{array}{c}\text { Delayed psychomotor development, early spasticity, dismorphic } \\
\text { features, TCC, central apnea. }\end{array}$ \\
\hline SPG50 & $\begin{array}{l}A P 4 M 1 \\
7 q 22.1\end{array}$ & $\begin{array}{l}\text { Adaptor-related protein } \\
\text { complex 4, mu } 1 \text { subunit }\end{array}$ & $\begin{array}{c}\text { Complicated/neonatal hypotonia that progresses to hypertonia. } \\
\text { Severe mental retardation. }\end{array}$ \\
\hline SPG51 & $\begin{array}{l}\text { AP4E1 } \\
15 q 21.2\end{array}$ & $\begin{array}{l}\text { Adaptor-related protein } \\
\text { complex } 5 \text {, zeta } 1 \text { subunit }\end{array}$ & $\begin{array}{l}\text { Complicated: neonatal hypotonia that progresses to hypertonia. } \\
\text { Severe mental retardation. Same phenotype as SPG50. }\end{array}$ \\
\hline SPG52 & $\begin{array}{l}\text { AP } 4 S 1 \\
14 \mathrm{q} 12\end{array}$ & AP4S1 & $\begin{array}{c}\text { Complicated: neonatal hypotonia that progresses to hypertonia. } \\
\text { Dysmorphic features. }\end{array}$ \\
\hline SPG53 & $\begin{array}{l}\text { Gene unknown } \\
\quad 8 p 22\end{array}$ & VSP37A & Complicated: psychomotor delay, spasticity of four limbs. \\
\hline SPG54 & $\begin{array}{l}\text { DDHD2 } \\
8 p 11\end{array}$ & Unknown & $\begin{array}{c}\text { Psychomotor delay, cognitive impairment, dismorphic features. TCC } \\
\text { and white matter lesions. }\end{array}$ \\
\hline SPG55 & $\begin{array}{l}\text { C12orf65 } \\
12 q 24.31\end{array}$ & C12orf65 & Early onset. Complicated: polyneuropathy and optic atrophy. \\
\hline SPG56 & $\begin{array}{l}\text { CYP2U1 } \\
4 \mathrm{q} .25\end{array}$ & CYP2U1 & Early onset, spasticity of four limbs, polyneuropathy. \\
\hline SPOAN & $\begin{array}{l}\text { Gene unknown } \\
11 \mathrm{q} 13\end{array}$ & Gene unknown & Early onset, spastic paraplegia, optic atrophy and axonal neuropathy. \\
\hline
\end{tabular}


may show specific findings such as thinning of the corpus callosum, white matter abnormalities and hydrocephalus, which will help guide further molecular testing. Spinal fluid analysis is warranted when history and previous tests did not exclude inflammatory and infectious myelopathies.

In the clinical setting of AD-HSP, screening for mutations in $S P G 4$ is the first step, followed by $S P G 3 a$ in negative cases $^{13,31}$. If spastic paraplegia initiated before the age of ten, SPG3a gene should be analyzed first. SPG31 is the next gene to be sequenced in negative cases ${ }^{32}$. Screening for these three genes will likely identify mutations in more than $50 \%$ of the patients.

Molecular investigation for AR-HSP should be guided by the complicating features. SPG11 is the most prevalent form of AR-HSP, its likelihood increases to up to $80 \%$ in the presence of cognitive decline and thinning of the corpus callosum $^{18}$. Currently in Brazil, patients must be referred to research centers for HSP gene sequencing.

Due to its phenotypic variability, the differentiation between various forms of HSP can be difficult on clinical grounds. In selected cases, it is reasonable to consider other neurodegenerative diseases on the differential diagnosis. Motor neuron disease, spinocerebellar ataxias, and neurodegeneration with brain-iron accumulation are conditions that may show clinical overlap with $\mathrm{HSP}^{33}$. Spinocerebellar ataxia type 3, also named Machado-Joseph disease, is the most common autosomal dominant spinocerebellar ataxia, and has been previously highlighted as a differential diagnosis for complicated HSP in Brazil ${ }^{34}$.

\section{PATHOPHYSIOLOGY}

HSPs are characterized by retrograde degeneration of the longest neurons of the spinal cord, the corticospinal tract and the posterior columns ${ }^{35}$. Due to their length and high metabolic needs, these neurons are highly susceptible to impaired transport of macromolecules and organelles. Despite its genetic heterogeneity, disruptive processes involving membrane trafficking and organelle morphogenesis and distribution seem to play a central role in the pathophysiology of most HSPs ${ }^{29,30,36}$.

HSP-related proteins cluster into overlapping functional classes: membrane trafficking, organelle shaping, mitochondrial regulation, lipid metabolism and axon path finding. The three most common AD-HSPs (SPG4, SPG3A, SPG31) are due to altered function of proteins involved in shaping the endoplasmic reticulum, a function highly dependent on microtubules ${ }^{37,38}$. Microtubule-targeting drugs have shown positive results in animal models of SPG4 ${ }^{39}$.

\section{NEUROIMAGING STUDIES}

In cases of proven HSP the most common neuroimaging finding is thinning of the spinal cord ${ }^{40}$. Although less frequent, brain abnormalities are often found in HSPs and this may be valuable to guide genotyping strategy. SPG11, the most common cause of AR-HSP, must be suspected when thinning of the corpus callosum is present, especially when accompanied by the ears of the linx sign (Figures $1 \mathrm{~A}$ and B) and widespread white matter abnormalities ${ }^{41,42,43}$. A recent study from our group showed that these patients also have significant grey matter volume reduction in specific cortical areas and the deep nuclei. These are the areas with higher expression of spastacsin in the brain and this pattern helps us to understand why movement disorders are so frequent in SPG $11^{42}$. Despite this, one must consider that thinning of the corpus callosum is not SPG11-specific, because it is also found in other HSPs such as: SPG 4, 7, 15, 18, 21, 46, 47, 49 and 54,11,21,44,45,46. Progressive hydrocephalus due to aqueductal stenosis is highly suggestive of X-linked SPG1. White matter abnormalities may be found in some ARHSP, such as SPG 5, SPG 21, SPG 35 or autosomal recessive spastic ataxia with leukoencephalopathy (ARSAL) ${ }^{47}$. In SPG2, white matter abnormalities are also typical; they resemble (but to a lesser extent) the diffuse hypomyelination found in the allelic Pelizaeus-Merzbacher disease $e^{25,48}$ (Figure 2).

Table 3. Current genetic classification of X-linked hereditary spastic paraplegia.

\begin{tabular}{|c|c|c|c|}
\hline Disease & Gene locus & Protein & Key clinical features \\
\hline $\begin{array}{l}\text { SPG1 } \\
\text { (MASA) }\end{array}$ & $\begin{array}{l}\text { L1CAM } \\
\text { Xq28 }\end{array}$ & $\begin{array}{l}\text { L1 cell adhesion } \\
\text { molecule }\end{array}$ & $\begin{array}{l}\text { Complicated: mental retardation, aphasia, shuffling gait, adducted thumbs. } \\
\text { Aqueductal stenosis wih hydrocephalus (MASA syndrome). }\end{array}$ \\
\hline SPG2 & $\begin{array}{l}P L P 1 \\
X q 22\end{array}$ & Proteolipid protein 1 & $\begin{array}{c}\text { Pure or complicated: optic atrophy, ataxia, mental retardation, } \\
\text { white matter lesions. }\end{array}$ \\
\hline SPG16 & $\begin{array}{l}\text { Gene unknown } \\
\quad \text { Xq11.2 }\end{array}$ & unknown & Pure or complicated: aphasia, mental retardation, impaired vision. \\
\hline SPG22 & Xq13.2 & $\begin{array}{l}\text { Monocarboxylate } \\
\text { transport } 8 \text { (MCT8) }\end{array}$ & $\begin{array}{l}\text { Complicated (Allan-Herndon-Dudley syndrome): congenital neck hypotonia, } \\
\text { psychomotor delay, early-spastcity, ataxia, dismorphic features. }\end{array}$ \\
\hline SPG34 & $\begin{array}{l}\text { Gen unknown } \\
\text { Xq24-q25 }\end{array}$ & unknown & Pure. All families described in Brazil. \\
\hline
\end{tabular}




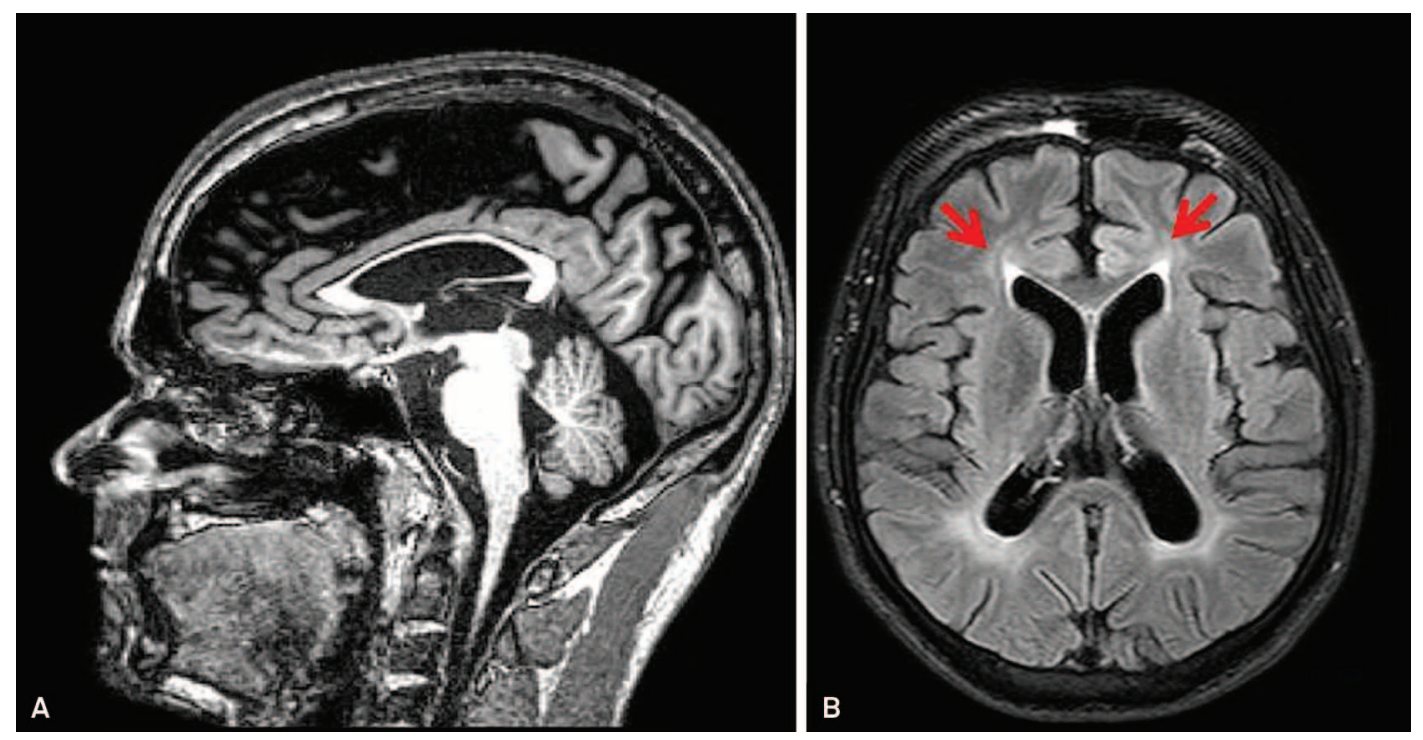

Figure 1. Magnetic resonance imaging of the brain of a patient with mutation in the SPG11 gene (SPG11 phenotype): Sagittal T1 weighted imaging showing thinning of the Corpus Callosum (A). Axial FLAIR imaging showing the "ears of the lynx" sign (red arrows) (B).

\section{FINAL REMARKS}

Despite the lack of disease modifying therapies, adequate prognostic counseling is of great importance for patients, family members and healthcare professionals. Outcome of patients with HSP is highly variable and specific molecular

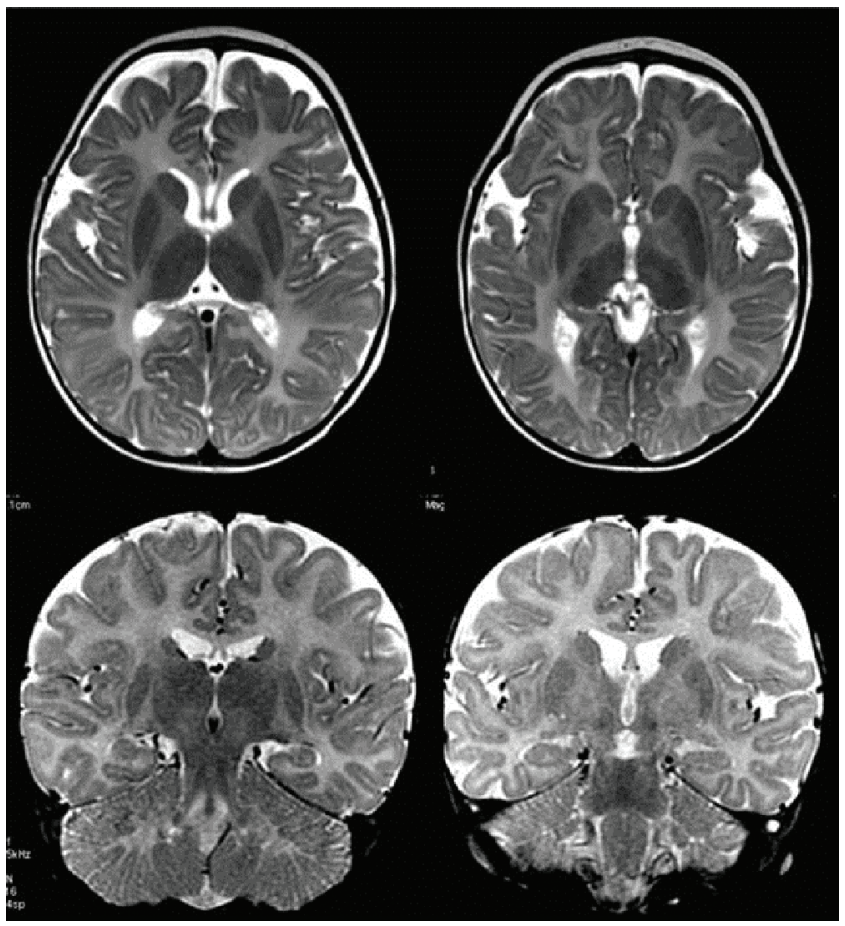

Figure 2. Magnetic resonance imaging of the brain of a patient with mutation in the PLP1 gene (SPG2 phenotype). Axial T2 weighted images show widespread hyperintensity along cerebral white matter. (Images from Professsor Maria Augusta Montenegro, Departamento de Neurologia, Universidade Estadual de Campinas). diagnosis provides more accurate information. Diagnosis is also warranted to prevent patients from been submitted to unnecessary diagnostic tests. Patients with pure HSP mostly have a normal life-spam. Wheelchair users, especially when this milestone is reached early in life, are more susceptible to secondary cardiovascular, pulmonary and infectious complications. In complex cases, prognosis is strongly determined by additional manifestations. The course of the spastic paraplegia itself is usually slowly progressive; in some patients with extremely early onset, the disease may even resemble a static condition such as diplegic cerebral palsy. Overall, disability in patients with pure HSP tends to progress slower than in patients with spinocerebellar ataxias ${ }^{49}$.

Spasticity is the most disabling feature in the majority of cases. Treatment options include oral anti-spastic agents, such as baclofen and tizanidine. If these drugs are ineffective, chemodenervation with botulinum toxins may be attempted $^{50,51}$. In our experience, the use of low doses of botulinum toxin associated with proper physical therapy (focused on stretching and strengthening) benefits the patientás ambulatory capacity, provides pain relief and prevents contractures and deformities. Signs and symptoms of parkinsonism should be actively investigated since it can be alleviated with dopaminergic drugs. Neuropathic pain is managed with antidepressants (amytriptiline, nortryptiline, duloxetin) or anticonvulsants (pregabalin, gapapentin). Urinary urgency can be alleviated with anticholinergic drugs ${ }^{52}$.

As the disease progresses patients should be evaluated for the appropriate assistive walking devices such as walkers and wheelchairs. In case of prominent distal weakness affecting foot dorsiflexion it is reasonable to use ankle-foot orthoses. Secondary deformities such as scoliosis, tendon contractures and foot deformities may require surgical management. 


\section{CONCLUSIONS}

HSP is a group of disorders in which the long motor neuron axons are predominantly affected, leading to slowly progressive pyramidal weakness of the lower limbs with relative preservation of other body parts. Phenotypic and genotypic heterogeneity contributes to under recognition of the dis- ease. Increasing awareness about this disorder is especially important for patients and researchers nowadays, since there is rapid progression on the field. Detection of new causative genes, HSP-related proteins and its mechanisms may bring treatment perspectives in the near future as well as provide clues about other similar neurodegenerative diseases of the motor system ${ }^{53}$.

\section{References}

1. Finsterer J, Loscher W, Quasthoff S, Wanschitz J, Aur-Grumbach M, Stevanin G. Hereditary spastic paraplegias with autosomal dominant, recessive, X-linked or maternal trait of inheritance. J Neurol Sci 2012;318:1-18.

2. Erichsen AK, Koht J, Stray-Pedersen A, Abdelnoor M, Tallaksen CME. Prevalence of hereditary ataxias and spastic paraplegia in southeast Norway: a population-based study. Brain 2009;132:1577-1588.

3. Coutinho P, Ruano L, Loureiro JL, et al. Hereditary ataxia and spastic paraplegia in Portugal a population-based prevalence study. Jama Neurol 2013;70:746-755.

4. O'Toole O, Traynor BJ, Brennan P, et al. Epidemiology and clinical features of amyotrophic lateral sclerosis in Ireland between 1995 and 2004. J Neurol Neurosurg Psychiatry 2008;79:30-32.

5. Chiò A, Logroscino G, Traynor BJ, et al. Global epidemiology of amyotrophic lateral sclerosis: a systematic review of the published literature. Neuroepidemiology 2013;41:118-130.

6. Vanacore N, Bonifati V, Fabbrini G, et al. Epidemiology of multiple system atrophy. ESGAP Consortium. European Study Group on Atypical Parkinsonisms. Neurol Sci 2001;22:97-99.

7. Kaplan JC, Hamroum D. Gene table neuromuscular disorders. Available at: http://www.musclegenetable.fr. Accessed at 08/27/2013.

8. Hazan J, Fonknechten N, Mavel D, et al. Spastin, a new AAA protein, is altered in the most frequent form of autosomal dominant spastic paraplegia. Nat Genet 1999;23:296-303.

9. França MC Jr, Dogini DB, D’Abreu A, et al. SPG4-related hereditary spastic paraplegia: frequency and mutation spectrum in Brazil. Accepted for publication on Clin Genet August 2013.

10. Mitne-Neto M, Kok F, Beetz C, et al. A multi-exonic SPG4 duplication underlies sex-dependent penetrance of hereditary spastic paraplegia in a large Brazilian pedigree. Eur J Hum Genet 2007;15:1276-1279

11. Orlacchio A, Kawarai T, Totaro A, Errico A, St George-Hyslop PH, Rugarli El, Bernardi G. Hereditary spastic paraplegia: clinical genetic study of 15 families. Arch Neurol 2004;61:849-855.

12. Fink JK. Hereditary spastic paraplegia: spastin phenotype and function. Arch Neurol 2004;61:830-833.

13. Namekawa M, Ribai P, Nelson I, et al. SPG3 A is the most frequent cause of hereditary spastic paraplegia with onset before age 10 years. Neurology 2006;66:112-114.

14. Züchner S, Wang G, Tran-Viet KN, Nance MA, et al. Mutations in the novel mitochondrial protein REEP1 cause hereditary spastic paraplegia type 31. Am J Hum Genet 2006;79:365-369.

15. Munhoz RP, Kawarai T, Teive HA, et al. Clinical and genetic study of a Brazilian family with spastic paraplegia (SPG6 locus). Mov Disord 2006;21:279-281.

16. Valdamis PN, Meijer IA, Reynolds A, et al. Mutations in the KIAA0196 gene at the SPG8 locus cause hereditary spastic paraplegia. Am J Hum Genet 2007:80:152-161.

17. Paisan-Ruiz C, Dogu O, Yilmaz A, Houlden H, Singleton A. SPG11 mutations are common in familial cases of complicated hereditary spastic paraplegia. Neurology 2008;70:1384-1389.
18. Stevanin G, Santorelli FM, Azzedine H, et al. Mutations in SPG11, encoding spatacsin, are a major cause of spastic paraplegia with thin corpus callosum. Nat Genet 2007;39:366-372.

19. Anheim M, Lagier-Tourenne C, Stevanin G, et al. SPG11 spastic paraplegia A new case of juvenile parkinsonism. J Neurol 2009;256:104-108.

20. França Jr. MC, D’Abreu A, Maurer-Morelli CV, et al. Prospective neuroimaging study in hereditary spastic paraplegia with thin corpus callosum. Mov Disorder 2007;22:1556-1562.

21. Goizet C, Boukhris A, Maltete D, et al. SPG15 is the second most common cause of hereditary spastic paraplegia with thin corpus callosum. Neurology 2009;73:1111-1119.

22. van Gassen KL, van der Heijden CD, de Bot ST, et al. Genotypephenotype correlations in spastic paraplegia type 7: a study in a large Dutch cohort. Brain 2012;135:2994-3004

23. Macedo-Souza LI, Kok F, Santos S, et al. Spastic paraplegia, optic atrophy, and neuropathy: new observations, locus refinement and exclusion of candidate genes. Ann Hum Genet 2009;73:382-387.

24. Jouet M, Rosenthal A, Armstrong $G$, et al. X-linked spastic paraplegia (SPG1), MASA syndrome and $X$-linked hydrocephalus result from mutations in the L1 gene. Nat Genet 1994;7:402-407.

25. Saugier-Veber P, Munnich A, Bonneau D, et al. X-linked spastic paraplegia and Pelizaeus-Merzbacher disease are allelic disorders at the proteolipid protein locus. Nat Genet 1994;6:257-262.

26. Starling A, Rocco P, Hobson GM, Bueno P, Zatz M. Further evidence for a fourth gene causing X-linked pure spastic paraplegia. Am J Med Genet 2002;111:152-156.

27. Macedo-Souza LI, Kok F, Santos S, et al. Reevaluation of a large family defines a new locus for $X$-linked recessive pure spastic paraplegia (SPG34) on chromosome Xq25. Neurogenetics 2008;9:225-226.

28. Verny C, Gugen N, Desquiret V, et al. Hereditary spastic paraplegialike disorder due to a mitochondrial ATP6 gene point mutation. Mitochondrion 2011;11:70-75.

29. Fink JK. Hereditary spastic paraplegia: clinico-pathologic features and emerging molecular mechanisms. Acta Neuropathol 2013;126:307-328.

30. Salinas S, Proukakis C, Crosby A, Warner TT. Hereditary spastic paraplegia: clinical features and pathogenetic mechanisms. Lancet Neurol 2008;7:1127-1138.

31. McMonagle P, Byrne PC, Fitzgerald MB, Webb S, Parfrey NA Hutchinson M. Phenotype of AD-HSP due to mutations in the SPAST gene: comparison with AD-HSP without mutations. Neurology 2000;55:1794-1800.

32. McCorquodale DS, Ozomaro U, Huang J, et al. Mutation screening of spastin, atlastin, and REEP1 in hereditary spastic paraplegia. Clin Genet 2011;79:523-530.

33. Orlacchio A, Babalini C, Borreca A, et al. SPATACSIN mutations cause autosomal recessive juvenile amyotrophic lateral sclerosis. Brain 2010;133:591-598.

34. Teive HAG, Iwamoto FM, Camargo CH, Lopes-Cendes I, Werneck LC Machado-Joseph Disease versus hereditary spastic paraplegia: case report. Arq Neuropsiquiatr 2001;59:809-811. 
35. Deluca GC, Ebers GC, Esiri MM. The extent of axonal loss in the long tracts in hereditary spastic paraplegia. Neuropathol Appl Neurobiol 2004;30:576-584.

36. Blackstone C. Cellular pathways oh hereditary spastic paraplegia. Annu Rev Neurosci 2012;35:25-47.

37. Blackstone C, O'Kane CJ, Reid E. Hereditary spastic paraplegias: membrane traffic and the motor pathways. Nature Rev 2011;12:31-42.

38. Park SH, Zhu PP, Parker RL, Blackstone C. Hereditary spastic paraplegia proteins REEP1, spastin, and atlastin-1 coordinate microtubule interactions with the tubular ER network. J Clin Invest 2010;120:1097-1100.

39. Fassier C, Tarrade A, Peris L, et al. Microtubule-targeting drugs rescue axonal swellings in cortical neurons from spastin knockout mice. Dis Model Mech 2013;6:72-83.

40. Hedera P, Eldevik OP, Maly P, Rainier S, Fink JK. Spinal cord magnetic resonance imaging in autosomal dominant hereditary spastic paraplegia. Neuroradiology 2005;47:730-734.

41. Hourani R, El-Hajj T, Barada WH, Hourani M, Yamout BI. MR Imaging findings in autosomal recessive hereditary spastic paraplegia. AJNR Am J Neuroradiol 2009;30:936-940

42. França Jr MC, Yasuda C, Pereira FRS, et al. White and grey matter abnormalities in patients with SPG11 mutations. J Neurol Neurosurg Psychiatry 2012;83:828-833.

43. Riverol M, Samaranch L, Pascual B, et al. Forceps minor region signal abnormality "ears of the lynx": an early MRI finding in spastic paraparesis with thin corpus callosum and mutations in the spatacsin gene (SPG11) on chromosome 15. J Neuroimaging 2009;19:52-60.

44. Simpson MA, Cross H, Proukakis C, et al. Maspardin is mutated in mast syndrome, a complicated form of hereditary spastic paraplegia associated with dementia. Am J Hum Genet 2003;73:1147-1156.
45. Boukhris A, Feki I, Elleuch N, Miladi MI, et al. A new locus (SPG46) maps to 9p21.2-q21.12 in a Tunisian family with a complicated autosomal recessive hereditary spastic paraplegia with mental impairment and thin corpus callosum. Neurogenetics. 2010;11:441-448.

46. Blumkin L, Lerman-Sagie T, Lev D, Yosovich K, Leshinsky-Silver E. A new locus (SPG47) maps to 1p13.2-1p12 in an Arabic family with complicated autosomal recessive hereditary spastic paraplegia and thin corpus callosum. J Neurol Sci 2011;305:67-70.

47. Bayat V, Thiffault I, Jaiswal M, et al. Mutations in the mitochondrial methionyl-tRNA synthetase cause a neurodegenerative phenotype in flies and a recessive ataxia (ARSAL) in humans. PLoS Biol 2012;10:1001288.

48. Steenweg ME, Vanderver A, Blaser S, et al. Magnetic resonance imaging pattern recognition in hypomyelinating disorders. Brain 2010;133:2971-2982.

49. Tezenas du Montcel S, Charles P, Goizet C, et al. Factors influencing disease progression in autosomal dominant cerebellar ataxia and spastic paraplegia. Arch Neurol 2012;69:500-508.

50. Comella CL, Pullman SL. Botulinum toxins in neurological disease. Muscle Nerve 2004;29:628-644.

51. Hecht MJ, Stolze $H$, Auf dem Brinke $M$, et al. Botulinum neurotoxin type $A$ injections reduce spasticity in mild to moderate hereditary spastic paraplegia-report of 19 cases. Mov Disord 2008;23:228-233.

52. Fourtassi M, Jacquin-Courtois S, Scheiber-Nogueira MC, et al. Bladder dysfunction in hereditary spastic paraplegia: a clinical and urodynamic evaluation. Spinal Cord 2012;50:558-562.

53. LeDoux MS. Non-Parkinson movement disorders Five new things. Neurol Clinical Practice 2013;3:22-28. 